\title{
Toxicity level of the tulathromycin on BHK cell culture and the effect on infective titers of foot and mouth disease viruses")
}

\author{
VELI GULYAZ, BANU BAYRI OZBILGE*, NESLIHAN TASCENE*, SUKRAN YILMAZ*, \\ YASEMIN GULTEKIN*, GONCA OZTAP, MUSTAFA HASOKSUZ**
}

\author{
Faculty of Veterinary Medicine, Department of Virology, Harran University, ŞanlıUrfa, Turkey \\ *FMD (Sap) Institute, Cankaya, Ankara, Turkey \\ **Istanbul University-Cerrahpaşa, Faculty of Veterinary Medicine, Department of Virology, Istanbul, Turkey
}

\section{Gulyaz V., Ozbilge B. B., Tascene N., Yilmaz S., Gultekin Y., Ulusoy A., Oztap G., Hasoksuz M. Toxicity level of the tulathromycin on BHK cell culture and the effect on infective titers of foot and mouth disease viruses}

\section{Summary}

The aim of the study was to evaluate the cytotoxicity of tulathromycin (macrolide antibiotic) on BHK-21 An30 cells and to determine the effect on FMD (Serotypes; A/TUR/11, O/TUR/07, Asia-1/TUR/15) virus propagation in vitro. In the result of MTT tests and cell culture studies, the non-toxic upper concentration of the tulathromycin limit for BHK-21 An30 cell culture was determined as $30 \mu \mathrm{g} / \mathrm{ml}$ in terms of cell morphologies and numbers. The mean FMD 146S virus particle values produced in BHK-21 An30 cell cultures containing $30 \mu \mathrm{g} / \mathrm{ml}$ of tulathromycin were found to be $0.47,0.57$ and $0.25 \mu \mathrm{g} / \mathrm{ml}$; the mean infective titer determined as $10^{7.03}, 10^{6.23}$ and $10^{7.40} \mathrm{pfu} / \mathrm{ml}$ for A/TUR/11, O/TUR/07 and Asia-1/TUR/15, respectively. In the FMD virus cultures produced with medium containing penicillin-streptomycin, the mean values of $146 \mathrm{~S}$ virus particles were determined to be A/TUR/11, O/TUR/07 and the Asia-1/TUR/15 serotypes were 0.50, 0.55, and 0.32 $\mu \mathrm{g} / \mathrm{ml}$, respectively, while the mean infective titers were $10^{7.46}, 10^{6.62}$ and $10^{7.73} \mathrm{pfu} / \mathrm{ml}$, respectively. As a result, it was concluded that tulathromycin can be used as an antibiotic up to $30 \mu \mathrm{g} / \mathrm{ml}$ in a BHK-21 An30 cell culture and in the production media of the FMD virus $\mathrm{A}$, $\mathrm{O}$, and Asia-1 serotypes.

Keywords: tulathromycin, BHK cell culture, FMDV, antibiotics, contamination

Traditionally, the term antibiotic refers to bactericides and bacteriostatics, that is, substances produced by microorganisms that, at low concentrations, respectively, kill or inhibit the growth of other microorganisms, but cause little or no host damage $(1,14,27,33)$.

These days, the application of cells in research laboratories, regenerative medicine, and biotechnological productions is growing extensively (9). Cells are used in wide-ranging activities, from studies on cell proliferation to the production of biologically active substances $(11,21)$. Antibiotics of the beta-lactam (penicillin) and aminoglycoside (streptomycin, neomycin, kanamycin, gentamicin) groups are widely used to reduce bacterial contamination risks in cell cultures (32). In addition, tylosin, tiamutin, enrofloxacin, and ciprofloxacin have been used therapeutically as ap-

This project was supported by the Ministry of Agriculture and Forestry, General Directorate of Agricultural Research and Policies (TAGEM/HSGYAD/15/ A02/P02/58). We thank Dr. M. Uğur Nuraloğlu, Ömer Şişman, and Ayşenur Ulusoy for their contributions to this project. proximately $5-35 \%$ intense mycoplasmas contaminations in cell cultures $(8,17,18,21,32)$.

Tulathromycin belongs to a new class of triamilide macrolides. Its 15 -membered ring comprising of 3 polar amine groups distinguishes it from other macrolides $(13,30)$. This semisynthetic derivative of erythromycin is used for the treatment and prevention of respiratory disease in cattle and swine. The therapeutic success of tulathromycin is partially attributed to its pharmacodynamic concentration in the appropriate tissues and low inhibitory concentrations against various bacterial pathogens $(7,16,30)$. Tulathromycin has a high affinity for uptake within bovine neutrophils. The antimicrobial properties of tulathromycin alone cannot fully explain its effectiveness in clearing the infection and inflammation associated with bovine respiratory disease (BRD), and recent observations support the hypothesis that the drug may promote the resolution of inflammation $(28,29)$ via mechanisms that are not fully understood (10). 
Foot and mouth disease (FMD) is the most contagious disease in mammals and has great potential for causing severe economic loss in susceptible clovenhoofed animals. There are seven serotypes of the FMD virus (FMDV), namely, O, A, C, SAT 1, SAT 2, SAT 3, and Asia-1 $(13,22)$. The serotypes of FMDV are not distributed uniformly around the world. The serotype $\mathrm{O}, \mathrm{A}$, and $\mathrm{C}$ viruses have had the widest distribution and have been responsible for outbreaks in Europe, America, Asia, and Africa. The FMDV particle is roughly spherical in shape, and, about $25-30 \mathrm{~nm}$ in diameter $(20,25)$. It consists of the RNA genome surrounded by a protein shell or capsid $(15,23)$. It causes heavy economic losses to the livestock industry, such as a high morbidity in adult animals, treatment costs, reduced milk production, loss of working ability in draught animals in developing countries, reproductive disorders, and high mortality in young ones $(13,19$, 24). The control of FMD is a national and regional responsibility, and, in many countries, the vaccine may be used only under the control of a veterinary authority $(20,35)$. Sensitive cell culture systems include primary bovine (calf) thyroid cells and primary pig, calf, or lamb kidney cells. Established cell lines, such as BHK-21 (baby hamster kidney) and IB-RS-2 cells, may also be used, but are generally less sensitive than primary cells for detecting low amounts of infectivity. The sensitivity of any cells used should be tested with the standard preparations of FMDV $(22,23)$. The FMD vaccine is obtained by producing BHK-21 cells under suspended conditions in high capacity reactors $(1000$, 3000 , and $5000 \mathrm{Lt}$ ). The concentration of highly immunogenic FMD $146 \mathrm{~S}$ particles is of great importance for FMD vaccine production $(3,6,29)$. The vaccine doses to be given to animals in FMD vaccine production are calculated in $\mu \mathrm{g} / \mathrm{ml}$ of FMD $146 \mathrm{~S}$ virus particles (5). As seen in other cell cultures and vaccine production processes, the biggest problems encountered in the FMD vaccine production are bacterial and fungal contaminations due to antimicrobial resistance. Therefore, the aim of our study was to evaluate the cytotoxicity of tulathromycin (macrolide antibiotic) in BHK-21 An30 cells and to determine its effect on the FMD virus propagation in vitro.

\section{Material and methods}

Tulathromycin (Pfizer-CP472.295). The antibiotic in the form of a powder was dissolved in distilled water, and $1,000 \mathrm{ppm}$ stock solution was prepared. The prepared stock solution was sterilized by passing through a $0.22 \mu \mathrm{m}$ porous filter. It was used by adding to the cell and virus production media according to the study concentrations.

Penicillin (Applichem-A1837) and streptomycin (Applichem-A1852). After preparing 10,000 ppm stock solutions of the antibiotics by dissolving them with distilled water, they were sterilized by filtering through a $0.22 \mu \mathrm{m}$ porous filter. Penicillin $100 \mathrm{IU} / \mathrm{ml}$ and streptomycin $50 \mu \mathrm{g} / \mathrm{ml}$ were used in the cell and virus cultures.
Cell culture. The BHK-21 An30 cell culture was obtained from the cell bank laboratory of the FMD (SAP) Institute.

Culture media (Applichem-A-1321). The Glasgow Minimum Essential Medium (GMEM) was used with fetal calf serum (Biochrom), inactivated at $56^{\circ} \mathrm{C}$ for 30 minutes and added (5\%-10\%) to the cell culture.

Viruses. FMD virus serotypes A, O, and Asia-1 type (A/TUR/11, O/TUR/07, Asia-1/TUR/15) were obtained from the FMD (SAP) Institute.

Methylthiazolyldiphenyl-tetrazolium bromide (MTT) test dye (Sigma-5655). The MTT dye was dissolved in a RPMI-1640 medium without phenol red, through a filter at $0.2 \mu \mathrm{m}$ filter and kept at $-20^{\circ} \mathrm{C}$.

Gum Tragacanth (Sigma 9000-65-1). Gum, which is used as a coating medium in determining the infective titer, was weighed in a proportion of $1.3 \%$ and then dissolved in distilled water. After autoclaving at $121^{\circ} \mathrm{C}$ for 20 minutes, it was mixed with 2 XGMEM medium in an equal volume and used by adding $1 \%$ sodium bicarbonate.

MTT test for cytotoxicity of tulathromycin in the BHK-21 An30 cells. An MTT test was performed to determine the toxicity of the tulathromycin in a BHK-21 An30 cell culture. The stock solution of the tulathromycin was diluted with a cell culture medium containing $10 \% \mathrm{FCS}$, and the final concentrations were obtained as 10, 20, 30, $40,50,60,70,80,90$, and $100 \mu \mathrm{g} / \mathrm{ml}$.

BHK-21 An30 cells were propagated as monolayer in 96 well plates, and a cell culture media with tulathromycin was added into the plate as $100 \mu \mathrm{l} /$ well before incubated in a $37^{\circ} \mathrm{C}$ incubator with $5 \% \mathrm{CO}_{2}$. Eight wells from top to bottom were used for each concentration of tulathromycin. In order to evaluate as a cell control, 16 wells were used for the medium without antibiotics, and 5 plates were prepared to evaluate at $24,48,72,96$, and 120 hours. At the end of each incubation period, the plates were taken and observed under a microscope, and then the media were removed. A free serum medium without antibiotics was placed as $100 \mu \mathrm{l}$ into the all wells. Later, an MTT dye (13 $\mu \mathrm{l} /$ well $)$ was dissolved at the time of use and added in a dark environment. All the plates were covered with aluminum foil and left in incubation at $37^{\circ} \mathrm{C}$ with $5 \% \mathrm{CO}_{2}$ for 4 hours. At the end of the incubation period, $100 \mu 1$ of isopropyl alcohol was added to each well by observing the formazan crystals. It was read at $570 \mathrm{~nm}$ in the spectrophotometer and the results were recorded (30).

Taking into account the first MTT test results, a new test was designed for the tulathromycin by determining new concentration ranges. For this purpose, the stock solutions of the tulathromycin were added to the cell culture media containing $10 \%$ serum at the final concentrations of 10,20 , 30 , and $40 \mu \mathrm{g} / \mathrm{ml}$. MTT tests of antibiotics at new concentration ranges were performed with the same procedure.

The results were evaluated according to the FMD (SAP) Institute protocol; A cytotoxicity test (with MTT) formula was used as:

$\%$ viability $=$ test $_{\text {absorbansort }} /$ Cell Control absorbansort $\times 100$.

According to the formula; the results were evaluated as non-toxic (>90\% cell viability), low toxic $(60-90 \%$ cell viability), moderately toxic (30-59\% cell viability), and toxic $(<30 \%)$. 
Effect of tulathromycin on morphology and proliferation of BHK-21 An30 cell. The cell culture media (GMEM) were prepared in final concentrations of 10, 30, 50, 80, 90, and $100 \mu \mathrm{g} / \mathrm{ml}$ using stock solutions of the antibiotics of the tulathromycin and the control group (penicillin-streptomycin). The BHK-21 An30 cells were trypsinized and resuspended with the antibiotic-free medium and divided into flasks. The GMEM prepared with antibiotic solutions were added into the flasks and incubated at $37^{\circ} \mathrm{C}$ with $5 \%$ $\mathrm{CO}_{2}$ for 48 hours. At the end of the $48^{\text {th }}$ hour, the monolayer ratio of the cells was observed. The media in the flasks were poured and made trypsinization. The cells in each flask were resuspended with their own media, and the cell numbers and morphological features were recorded with the burker slide method. According to the results obtained in the first concentrations, a second concentration range was determined, and the cell culture media were prepared as final concentration $10,20,30$, and $40 \mu \mathrm{g} / \mathrm{ml}$, and the test was repeated three times at the new concentration rates. At the end of 48-hour incubation periods of the cells, the monolayer ratios of the cells were observed, and the cell numbers and morphological properties of the cells resuspended by trypsinization were determined by using the burker slide method.

Effect of tulathromycin on the FMD virus propagation. The A, O, and Asia-1 serotypes of the FMD viruses with the ratio of 1 virus to 50-100 cells were inoculated into BHK-21 An30 cells propagated with the medium containing tulathromycin and control group antibiotics (penicillinstreptomycin) up to the $3^{\text {rd }}$ passage level in $25 \mathrm{~cm}^{2}$ flasks. After the incubation period for the virus adsorption, the virus propagation medium with tulathromycin and penicillinstreptomycin as put into each flask. The flasks were incubated in an incubator at $37^{\circ} \mathrm{C}$ with $5 \% \mathrm{CO}$ and $100 \% \mathrm{CPE}$ formation times were recorded in the cells. After 100\% CPE was seen in the cells, the flasks were frozen and thawed, and then centrifuged at 3,000 rpm for 10 minutes. The same procedures were repeated three times.

Detection of FMD $146 S$ virus particle. The SDG (Sucrose Density Gradient) method was performed according to the FMD Institute protocol. A linear gradient was obtained with a stratification in the ultra-centrifuge tube with $45 \%$ sucrose at the bottom and $15 \%$ sucrose at the top by the help of the gradient maker. A total of $0.5 \mathrm{ml} \mathrm{FMD}$ virus sample was added slowly over the gradient and then the tubes were centrifuged at $41,000 \mathrm{rpm}$ for 2 hours at $4^{\circ} \mathrm{C}$ in a vacuum environment of ultra-centrifuge. After that, the samples were placed on the apparatus by piercing the tube bottom through the $60 \%$ sucrose at a suitable flow rate to pass through with a computer-connected UV detector on $254 \mathrm{~nm}$. When the sample passed through the detector, the appropriate absorbance width set, and the Chroma Simple software program was started. After providing the peak in the program, the start and end point of the peak was drawn, and then finally the $146 \mathrm{~S}$ amount of sample was measured in $\mu \mathrm{g} / \mathrm{ml}$.

Infective titer of FMD virus. To determine the infective titer and examine the plaque characters of the FMD viruses produced in the BHK-21 An30 cell culture with media containing penicillin-streptomycin and tulathromycin, dilutions of the FMD virus from $\log 1010^{-1}$ to $10^{-6}$ were performed, and $100 \mu \mathrm{l}$ of each virus dilution was inoculated into the monolayer BHK-21 An30 cell culture prepared in 6-well plates. The plates were incubated at $37^{\circ} \mathrm{C}$ with $5 \% \mathrm{CO}$ for 1 hour, after which $3 \mathrm{ml}$ GMEM medium with 50\% GUM was added to each well of the plate. The plates were incubated again at $37^{\circ} \mathrm{C}$ with $5 \% \mathrm{CO}_{2}$ for 48 hours. At the end of the period, the media were emptied and a $2 \mathrm{ml}$ staining solution prepared with crystal violet was added to each plate well. Finally, the staining solution on the plates was drained and then washed three times with deionized water. To evaluate the plaque test result, the most recent dilution with plaques were counted, and the infective titer PFU/ $\mathrm{ml}$ was calculated using the formula (the dilution with the plaques $\mathrm{X}$ logarithm of the mean plaque number/inoculation volume) (3).

Statistical analysis. All the data were analyzed with Shapiro-Wilk and Levene Statistical tests. According to these two statistical results, the Independent Samples t-Test was performed for each of the three studies to detect the differences of the levels of the FMD $146 \mathrm{~S}$ viral particles and infective titers of the FMD virus serotypes between the control in the BHK-21 An30 cell culture with the media containing penicillin-streptomycin and the other one containing $30 \mu \mathrm{g} / \mathrm{ml}$ tulathromycin. The statistical results were evaluated on the $95 \%$ confidence interval. The SPSS 22.0 (Inc., Chicago II, USA) software was used.

\section{Results and discussion}

MTT test for cytotoxicity of tulathromycin in the BHK-21 An30 cells. The test was performed at the end of the 5-day incubation periods of the BHK-21 An30 cells produced by GMEM media, which were prepared with an antibiotic concentration started from $10,20,30,40,50,60,70,80,90$, and $100 \mu \mathrm{g} / \mathrm{ml}$. Then the cell viability was measured at $100 \%$ and above the absorbances in all the dilutions of the penicillin-streptomycin. The cell viability in the cell culture, including the tulathromycin at a concentration of $40 \mu \mathrm{g} / \mathrm{ml}$, was measured at $87.95 \%$ and continued to decrease at subsequent concentrations with an absorbance of $69.09 \%$ in $100 \mu \mathrm{g} / \mathrm{ml}$ (Fig. 1).

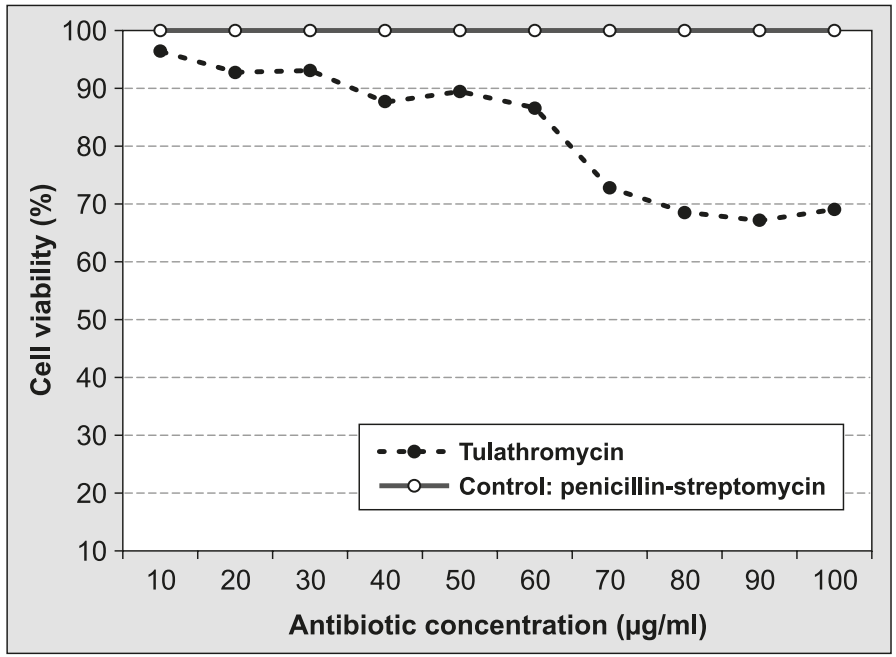

Fig. 1. MTT test for the cytotoxicity of tulathromycin and penicillin-streptomycin on BHK-21 An30 cells 
The MTT test was performed in the second concentration ranges started from 10, 20, 30, and $40 \mu \mathrm{g} / \mathrm{ml}$ via the evaluation of the first MTT test results. The cell viability was measured at $100 \%$ and above absorbances in the BHK-21 An30 cell cultures produced with a medium containing penicillin-streptomycin. The cell viability was measured at over $90 \%$ in the BHK-21 An30 cell cultures produced with the media containing $10 \mu \mathrm{g} / \mathrm{ml}$ and $30 \mu \mathrm{g} / \mathrm{ml}$ tulathromycin. Meanwhile, the cell viability was decreased from $72.89 \%$ to $50.94 \%$ in the last concentration of the cell cultures with a medium containing tulathromycin at the concentrations between 40 and $100 \mu \mathrm{g} / \mathrm{ml}$ and above.

Effect of tulathromycin on morphology and proliferation of BHK-21 An30 cell. As a result of passages with the BHK-21 An30 cell, it was observed that the cell numbers produced media containing tulathromycin at 10 and $30 \mu \mathrm{g} / \mathrm{ml}$ concentrations which were equivalent to the control group cell numbers at each passage. At $50 \mu \mathrm{g} / \mathrm{ml}$ and above concentrations, it was seen that the cell coverage rate and numbers decreased and degenerations started in the cell morphology (Tab. 1). As a result of repeated passages with the BHK-21 An 30 cell by narrowing the concentration ranges, it was observed that the cell numbers passaged medium with tulathromycin at 10,20 , and $30 \mu \mathrm{g} / \mathrm{ml}$ concentrations were equivalent to the control group cell numbers in each passage. At $40 \mu \mathrm{g} / \mathrm{ml}$ concentration, the cell coverage rate and numbers decreased and degenerations started in the cell morphology (Tab. 2). The $30 \mu \mathrm{g} / \mathrm{ml}$ of Tulathromycin was determined as an upper limit, and the BHK-21 An30 cells were replicated for the FMD virus inoculation.

Effect of tulathromycin on the FMD virus propagation. Following the inoculation of the $\mathrm{A}, \mathrm{O}$, and Asia-1 serotypes of the FMD virus in $25 \mathrm{~cm}^{2}$ flasks, it was noted that $100 \% \mathrm{CPE}$ was observed at an average of 30 hours in A/TUR/11, 21 hours in O/TUR/07, and 24 hours in Asia-1/TUR/15 FMDV, respectively. 146S virus particle and infective titer tests were performed from the virus suspension after by freezing-thawing the flasks and centrifuging at 3,000 rpm for 10 minutes.

Detection of FMD $146 \mathrm{~S}$ virus particle. In the FMDV suspensions produced three times with the virus media containing the control group antibiotics (penicillin-streptomycin), the mean value of the FMD $146 \mathrm{~S}$ virus particle was detected as $0.52,0.47$, and $0.53 \mu \mathrm{g} / \mathrm{ml}$ for A/TUR/11;0.6, 0.55 and $0.52 \mu \mathrm{g} / \mathrm{ml}$ for $\mathrm{O} / \mathrm{TUR} / 07$; and $0.32,0.28$ and $0.37 \mu \mathrm{g} / \mathrm{ml}$ for Asia-1/TUR/15 FMDV. The mean values of the FMD $146 \mathrm{~S}$ virus particle in the virus cultures made with the medium containing tulathromycin were $0.47 \mu \mathrm{g} / \mathrm{ml}$ for $\mathrm{A} / \mathrm{TUR} / 11,0.54 \mu \mathrm{g} / \mathrm{ml}$ for $\mathrm{O} / \mathrm{TUR} / 07$, and $0.25 \mu \mathrm{g} / \mathrm{ml}$ for Asia-1/TUR/15 (Tab. 3).

Tab. 1. Cell numbers and confluent ratios in first monolayer cell cultures

\begin{tabular}{|c|c|c|c|c|c|c|c|}
\hline \multirow{2}{*}{ Antibiotics } & \multirow{2}{*}{$\begin{array}{l}\text { Amount } \\
(\mu \mathrm{g} / \mathrm{ml})\end{array}$} & \multicolumn{2}{|c|}{ Cell Study 1} & \multicolumn{2}{|c|}{ Cell Study 2} & \multicolumn{2}{|c|}{ Cell Study 3} \\
\hline & & Confluent (\%) & Count & Confluent (\%) & Count & Confluent (\%) & Count \\
\hline \multirow{5}{*}{$\begin{array}{l}\text { Control } \\
\text { (Penicillin-Streptomycin) }\end{array}$} & 10 & 100 & $1.1 \times 10^{6}$ & 100 & $9.5 \times 10^{5}$ & 100 & $1.0 \times 10^{6}$ \\
\hline & 30 & 100 & $1.0 \times 10^{6}$ & 100 & $8.5 \times 10^{5}$ & 100 & $1.0 \times 10^{6}$ \\
\hline & 50 & 100 & $1.0 \times 10^{6}$ & 100 & $8.0 \times 10^{5}$ & 100 & $9.0 \times 10^{5}$ \\
\hline & 80 & 100 & $1.0 \times 10^{6}$ & 100 & $8.0 \times 10^{5}$ & 100 & $9.5 \times 10^{5}$ \\
\hline & 100 & 100 & $1.0 \times 10^{6}$ & 100 & $9.0 \times 10^{5}$ & 100 & $8.0 \times 10^{5}$ \\
\hline \multirow{5}{*}{ Tulathromycin } & 10 & 100 & $1.0 \times 10^{6}$ & 100 & $8.5 \times 10^{5}$ & 100 & $9.0 \times 10^{5}$ \\
\hline & 30 & 100 & $9.0 \times 10^{5}$ & 100 & $8.5 \times 10^{5}$ & 100 & $8.0 \times 10^{5}$ \\
\hline & 50 & 90 & $7.5 \times 10^{5}$ & 70 & $5.7 \times 10^{5}$ & 70 & $6.0 \times 10^{5}$ \\
\hline & 80 & 90 & $7.5 \times 10^{5}$ & 60 & $4.3 \times 10^{5}$ & 60 & $5.2 \times 10^{5}$ \\
\hline & 100 & 90 & $7.5 \times 10^{5}$ & 60 & $4.2 \times 10^{5}$ & 60 & $5.0 \times 10^{5}$ \\
\hline
\end{tabular}

Tab. 2. Cell numbers and confluent ratios in second monolayer cell cultures

\begin{tabular}{|c|c|c|c|c|c|c|c|}
\hline \multirow{2}{*}{ Antibiotics } & \multirow{2}{*}{ Amount $(\mu \mathrm{g} / \mathrm{ml})$} & \multicolumn{2}{|c|}{ Cell Study 1} & \multicolumn{2}{|c|}{ Cell Study 2} & \multicolumn{2}{|c|}{ Cell Study 3} \\
\hline & & Confluent (\%) & Count & Confluent (\%) & Count & Confluent (\%) & Count \\
\hline \multirow{4}{*}{$\begin{array}{l}\text { Control } \\
\text { (Penicillin-Streptomycin) }\end{array}$} & 10 & 100 & $1.1 \times 10^{6}$ & 100 & $9.5 \times 10^{5}$ & 100 & $1.0 \times 10$ \\
\hline & 20 & 100 & $9.5 \times 10^{5}$ & 100 & $1.0 \times 10^{6}$ & 100 & $9.5 \times 10$ \\
\hline & 30 & 100 & $1.0 \times 10^{6}$ & 100 & $9.5 \times 10^{5}$ & 100 & $1.0 \times 10$ \\
\hline & 40 & 100 & $9.5 \times 10^{5}$ & 100 & $1.0 \times 10^{6}$ & 100 & $1.0 \times 10$ \\
\hline \multirow{4}{*}{ Tulathromycin } & 10 & 100 & $9.6 \times 10^{5}$ & 100 & $9.5 \times 10^{5}$ & 100 & $9.0 \times 10$ \\
\hline & 20 & 100 & $1.0 \times 10^{6}$ & 100 & $9.5 \times 10^{5}$ & 100 & $8.5 \times 10$ \\
\hline & 30 & 100 & $1.0 \times 10^{6}$ & 100 & $9.0 \times 10^{5}$ & 100 & $9.0 \times 10^{0}$ \\
\hline & 40 & 100 & $7.0 \times 10^{5}$ & 90 & $7.5 \times 10^{5}$ & 80 & $7.5 \times 10$ \\
\hline
\end{tabular}


Tab. 3. Amounts of FMD $146 \mathrm{~S}$ viral particles produced with medium containing tulathromycin

\begin{tabular}{|c|c|c|c|c|c|c|c|c|c|c|c|c|c|}
\hline \multirow{3}{*}{ Treatments } & \multirow{3}{*}{ Items } & \multicolumn{12}{|c|}{ Levels of FMD 146 S viral particles $(\mu \mathrm{g} / \mathrm{ml})$} \\
\hline & & \multicolumn{4}{|c|}{ A Tur.11 } & \multicolumn{4}{|c|}{0 Tur. 07} & \multicolumn{4}{|c|}{ Asia-1 Tur.15 } \\
\hline & & $\begin{array}{c}\text { Mean } \\
\text { Value } \\
(\overline{\mathbf{x}})\end{array}$ & SD & SEM & $\begin{array}{c}p \\
\text { value }\end{array}$ & $\begin{array}{c}\text { Mean } \\
\text { Value } \\
(\bar{x})\end{array}$ & SD & SEM & $\begin{array}{c}\mathrm{p} \\
\text { value }\end{array}$ & $\begin{array}{c}\text { Mean } \\
\text { Value } \\
(\bar{x})\end{array}$ & SD & SEM & $\begin{array}{c}p \\
\text { value }\end{array}$ \\
\hline Control & Study 1 & 0.517 & 0.007 & 0.020 & \multirow{2}{*}{0.001} & 0.600 & 0.012 & 0.004 & \multirow{2}{*}{0.069} & 0.320 & 0.01 & 0.007 & \multirow{2}{*}{0.003} \\
\hline Tulathromycin $(30 \mu \mathrm{g} / \mathrm{ml})$ & Study 1 & 0.548 & 0.013 & 0.050 & & 0.620 & 0.023 & 0.008 & & 0.280 & 0.02 & 0.008 & \\
\hline Control & Study 2 & 0.470 & 0.012 & 0.004 & \multirow{2}{*}{0.001} & 0.554 & 0.010 & 0.004 & \multirow{2}{*}{0.038} & 0.280 & 0.02 & 0.008 & \multirow{2}{*}{0.025} \\
\hline Tulathromycin $(30 \mu \mathrm{g} / \mathrm{ml})$ & Study 2 & 0.414 & 0.01 & 0.005 & & 0.530 & 0.020 & 0.009 & & 0.252 & 0.01 & 0.006 & \\
\hline Control & Study 3 & 0.530 & 0.025 & 0.009 & \multirow{2}{*}{0.001} & 0.522 & 0.013 & 0.005 & \multirow{2}{*}{0.001} & 0.365 & 0.01 & 0.006 & \multirow{2}{*}{0.001} \\
\hline Tulathromycin $(30 \mu \mathrm{g} / \mathrm{ml})$ & Study 3 & 0.450 & 0.017 & 0.006 & & 0.462 & 0.017 & 0.006 & & 0.230 & 0.02 & 0.008 & \\
\hline Total values for Control & Study 1-2-3 & 0.505 & 0.01 & 0.004 & \multirow[b]{2}{*}{0.001} & 0.559 & 0.007 & 0.002 & \multirow[b]{2}{*}{0.002} & 0.321 & 0.01 & 0.004 & \multirow[b]{2}{*}{0.001} \\
\hline $\begin{array}{l}\text { Total values for } \\
\text { Tulathromycin }(30 \mu \mathrm{g} / \mathrm{ml})\end{array}$ & Study 1-2-3 & 0.470 & 0.009 & 0.003 & & 0.537 & 0.01 & 0.004 & & 0.254 & 0.01 & 0.004 & \\
\hline
\end{tabular}

Explanation: control - includes penicillin-streptomycin; SD - standard deviation; SEM - standard error mean; $p-$ significance $(p<0.05)$

Tab. 4. Infective titers of FMD virus produced by media with tulathromycin

\begin{tabular}{|c|c|c|c|c|c|c|c|c|c|c|c|c|c|}
\hline \multirow{3}{*}{ Treatments } & \multirow{3}{*}{ Items } & \multicolumn{12}{|c|}{ Infective titers of FMD serotypes (pfu/ml) } \\
\hline & & \multicolumn{4}{|c|}{ A Tur.11 } & \multicolumn{4}{|c|}{0 Tur. 07} & \multicolumn{4}{|c|}{ Asia-1 Tur.15 } \\
\hline & & $\begin{array}{l}\text { Mean } \\
\text { Value } \\
(\bar{x})\end{array}$ & SD & SEM & $\begin{array}{c}p \\
\text { value }\end{array}$ & $\begin{array}{l}\text { Mean } \\
\text { Value } \\
(\bar{x})\end{array}$ & SD & SEM & $\begin{array}{c}p \\
\text { value }\end{array}$ & $\begin{array}{l}\text { Mean } \\
\text { Value } \\
(\bar{x})\end{array}$ & SD & SEM & $\begin{array}{c}p \\
\text { value }\end{array}$ \\
\hline Control & Study 1 & 7.75 & 0.01 & 0.005 & \multirow{2}{*}{0.001} & 6.72 & 0.021 & 0.008 & \multirow{2}{*}{0.001} & 8.14 & 0.01 & 0.006 & \multirow{2}{*}{0.001} \\
\hline Tulathromycin $(30 \mu \mathrm{g} / \mathrm{ml})$ & Study 1 & 7.48 & 0.02 & 0.009 & & 6.46 & 0.014 & 0.005 & & 8.02 & 0.01 & 0.005 & \\
\hline Control & Study 2 & 7.21 & 0.02 & 0.009 & \multirow{2}{*}{0.001} & 6.00 & 0.01 & 0.007 & \multirow{2}{*}{0.004} & 7.43 & 0.02 & 0.010 & \multirow{2}{*}{0.001} \\
\hline Tulathromycin $(30 \mu \mathrm{g} / \mathrm{ml})$ & Study 2 & 6.76 & 0.03 & 0.011 & & 5.96 & 0.02 & 0.008 & & 7.10 & 0.02 & 0.010 & \\
\hline Control & Study 3 & 7.43 & 0.02 & 0.010 & \multirow{2}{*}{0.001} & 6.53 & 0.033 & 0.012 & \multirow{2}{*}{0.001} & 7.62 & 0.04 & 0.010 & \multirow{2}{*}{0.001} \\
\hline Tulathromycin $(30 \mu \mathrm{g} / \mathrm{ml})$ & Study 3 & 6.85 & 0.06 & 0.020 & & 6.28 & 0.039 & 0.014 & & 7.03 & 0.06 & 0.020 & \\
\hline Total values for Control & Study 1-2-3 & 7.463 & 0.018 & 0.006 & \multirow[b]{2}{*}{0.001} & 6.417 & 0.01 & 0.003 & \multirow[b]{2}{*}{0.001} & 7.730 & 0.01 & 0.007 & \multirow[b]{2}{*}{0.001} \\
\hline $\begin{array}{l}\text { Total values for } \\
\text { Tulathromycin }(30 \mu \mathrm{g} / \mathrm{ml})\end{array}$ & Study 1-2-3 & 7.033 & 0.032 & 0.012 & & 6.234 & 0.015 & 0.005 & & 7.390 & 0.01 & 0.007 & \\
\hline
\end{tabular}

Explanation: as in Tab. 3.

Infective titer of FMD virus. In the plaque tests, the FMD viruses produced with a medium containing penicillin-streptomycin were determined to be $10^{7.46}, 10^{6.42}$ and $10^{7.73} \mathrm{pfu} / \mathrm{ml}$ for serotypes A/TUR/11, O/TUR/07 and Asia-1/TUR/15, respectively. The FMD infective virus titers produced with a medium containing tulathromycin were determined as $10^{7.03}, 10^{6.23}$ and $10^{7.40} \mathrm{pfu} / \mathrm{ml}$ for the serotypes A/TUR/11 O/TUR/07 Asia-1/TUR/15, respectively (Tab. 4).

Statistical analysis. The results of the $146 \mathrm{~S}$ virus particles produced in the BHK-21 An30 cell cultures with tulathromycin for the FMDV serotype A/TUR/11 showed a statistically significant increase $(p<0.05)$. In other studies of the FMDV serotypes, the data was very close numerically. It was determined that the tulathromycin had a positive effect. However, a statistically significant difference was found in the lower mean values of $146 \mathrm{~S}$ virus particles compared to the control group antibiotics (penicillin-streptomycin). To compare with the infective titers, close values were found, but a statistically significant decrease was observed $(\mathrm{p}<0.05)$.

In conclusion, although the effect of this study result was not observed as being equivalent to the penicillin-streptomycin control group, the level of $30 \mu \mathrm{g} / \mathrm{ml}$ tulathromycin in the virus-producing media showed a positive activity and resulted in the same infective titer when compared to the control group values. Finally, it was concluded that this concentration of tulathromycin could be used as an alternative in the virus culture media.

The most widely used antibiotics in cell cultures are penicillin $(50-100 \mathrm{IU} / \mathrm{ml})$, streptomycin $(50-100 \mu \mathrm{g} /$ $\mathrm{ml})$, and gentamicin sulfate $(50-100 \mu \mathrm{g} / \mathrm{ml})$. In addition, kanamycin sulfate $(100 \mu \mathrm{g} / \mathrm{ml})$, neomycin sulfate $(50 \mu \mathrm{g} / \mathrm{ml})$, ampicillin $(100 \mu \mathrm{g} / \mathrm{ml})$, carbenicillin $(0.1-75 \mu \mathrm{g} / \mathrm{ml})$, chloramphenicol $(5 \mu \mathrm{g} / \mathrm{ml})$, ciprofloxacin $(10 \mu \mathrm{g} / \mathrm{ml})$ and tetracycline $(10 \mu \mathrm{g} / \mathrm{ml})$ are commonly used as antibiotics in cell cultures. These rates recommended for antibiotics were determined 
for serum-containing media. These rates are usually reduced by $50 \%$ due to the increased cytotoxic effect of antibiotics in serum-free conditions. In addition, attempts are made to expand the effects of antibiotics by combining them to create synergistic effects $(4,26,27)$.

This study aimed to use tulathromycin as an antibiotic in BHK-21 An30 cell cultures (and widely used in FMD vaccine production), as an alternative to some currently available antibiotics (penicillin and streptomycin).

In a study to determine the toxicity of some macrolide group antibiotics (tilmicosin-TILM, tylosin-TYL and spiramycin-SPI) at different concentrations (50$-1000 \mu \mathrm{g} / \mathrm{ml}$ ) on the BHK 21 cell cultures (cell line from young hamster kidneys), it was reported that spiramycin did not have a significant effect on the viability in cells up to $125 \mu \mathrm{g} / \mathrm{ml}$, but the cells rapidly lost their viability at 150 and $200 \mu \mathrm{g} / \mathrm{ml}$, and complete deaths occurred in cells above $300 \mu \mathrm{g} / \mathrm{ml}$. In the same study, it was reported that $70 \%$ of sub vital formations were detected even at $50 \mu \mathrm{g} / \mathrm{ml}$ of BCC cells (10). In our present study, cell viability was measured as $100 \%$ in all the dilutions of the penicillin-streptomycin in the MTT test, and the cell viability was found to be over $90 \%$ in the BHK-21 An30 cell cultures produced with the media containing tulathromycin of 10 and $30 \mu \mathrm{g} / \mathrm{ml}$, and it was observed in concentrations between 40 and $100 \mu \mathrm{g} / \mathrm{ml}$, and above that the cell viability dropped from $72.89 \%(40 \mu \mathrm{g} / \mathrm{ml})$ to $50.94 \%$ in the last concentration $(100 \mu \mathrm{g} / \mathrm{ml})$. In the present study it was observed that the toxicity amount ( $40 \mu \mathrm{g} / \mathrm{ml}$ and above) in the BHK-21 An30 cell culture for the tulathromycin in the macrolides antibiotics group was higher than the amount for the spiramycin (above $125 \mu \mathrm{g} / \mathrm{ml}$ ) and tylosin (above $500 \mu \mathrm{g} / \mathrm{ml}$ ) reported by Fülöpová et al. (10), but lower than the values reported for tilmicosin $(0-50 \mu \mathrm{g} / \mathrm{ml})$.

At the end of the three passages of the BHK-21 An30, with the cells made with the medium containing tulathromycin in concentrations of 10, 20, and $30 \mu \mathrm{g} / \mathrm{ml}$, it was observed that the cell numbers were equivalent to the cell numbers of the control group (penicillin-streptomycin) in every passage. At $40 \mu \mathrm{g} / \mathrm{ml}$ concentration, it was determined that the cell coverage rate and numbers decreased and degenerations occurred in the cell morphology.

FMD, one of the most devastating diseases of livestock, can cause significant economic losses worldwide, and remains the most important constraint to international trade in live animals and animal products $(15,19,29)$. FMDV is divided into seven serotypes with no cross-protection conferred among those serotypes $(23,35)$. Vaccination is very important in combating the FMD disease. The production of vaccines against the FMD disease is carried out in suspended BHK cell cultures $(5,23)$. One of the most important problems encountered during vaccine production is the bacterial contamination of the cell cultures. The use of antibiotics as a preservative against bacterial contamination, which is one of the biggest problems in the production of cell cultures, has become imperative, especially in large-scale systems $(28,31$, $32,34)$. Gentamycin, penicillin, and streptomycin are routinely used for protective purposes against bacterial contamination in the production of large volumes of FMD vaccine.

The concentration of highly immunogenic FMD $146 \mathrm{~S}$ particles is of great importance for FMD vaccine production $(3,6,29)$. Vaccine doses to be given to animals in FMD vaccine production are calculated in $\mu \mathrm{g} / \mathrm{ml}$ of FMD $146 \mathrm{~S}$ virus particles (5). In the study conducted by us, the average FMD 146 S virus particle amounts obtained in the vaccine suspension produced by the medium containing penicillin-streptomycin (A/TUR/11, O/TUR/07, and the Asia-1/TUR/15 were $0.50 \mu \mathrm{g} / \mathrm{ml}, 0.55 \mu \mathrm{g} / \mathrm{ml}$ and $0.32 \mu \mathrm{g} / \mathrm{ml}$, respectively) and were observed to be very close to the amount of 146S FMD virus particle produced with the medium containing $30 \mu \mathrm{g} / \mathrm{ml}$ of tulathromycin $(\mathrm{A} / \mathrm{TUR} / 11$, $\mathrm{O} / \mathrm{TUR} / 07$, and Asia-1/TUR/15 were $0.47 \mu \mathrm{g} / \mathrm{ml}$, $0.53 \mu \mathrm{g} / \mathrm{ml}$ and $0.25 \mu \mathrm{g} / \mathrm{ml}$, respectively).

In conclusion, tulathromycin is suitable for the use of up to $30 \mu \mathrm{g} / \mathrm{ml}$ according to the spectrum of action, and can be used in the BHK-21 An30 cultures against contaminations caused by bacteria and the FMD vaccine production process.

\section{References}

1. Akkan H. A., Karaca M.: Veteriner iç hastalıklarında antibiyotiklerin kullanımı. YYÜ Vet. Fak. Derg. 2003, 14, 72-77.

2. Baer A., Kehn-Hall K.: Viral concentration determination through plaque assays: using traditional and novel overlay systems. J. O. V. E. 2014, 93, 1-10.

3. Basagoudanavar S. H., Hosamani M., Selvan R. P. T., Sreenivasa B. P., Saravanan P., Sagar B. K. C., Venkataramanan R.: Development of a liquidphase blocking ELISA based on foot-and-mouth disease virus empty capsid antigen for seromonitoring vaccinated animals. Arch. Virol. 2013, 158, 993-1001.

4. Campos C. O., Bernuci M. P., Vireque A. A., Campos J. R., Silva-de-S'M. F., Jamur M. C., Rosa-e-Silva A. C. J. S.: Preventing microbial contamination during long-termin vitro culture of human granulosa-lutein cells: an ultrastructural analysis. ISRN Obstetrics and Gynecology 2012, Article ID 152781, 1-6.

5. Cokçalışkan C., Türkoğlu T., Sareyyüpoğlu B., Uzunlu E., Babak A., Özbilge $B$. B., Gülyaz $V$ : Qs-21 enhances the early antibody response to oil adjuvant foot and mouth disease vaccine in cattle. Clin. Exp. Vac. Res. 2016, 5, 138-147.

6. Doronin M. I., Timina A. M., Lozovoy D. A., Starikov V. A., Mikhalishin D. V., Medvedeva N. N., Borisov A. V.: Method for FMD virus 146S component concentration determination with real-time reverse transcription-polymerase chain reaction in vaccine raw materials. Vet. Sci. Today 2018, 2.

7. Fischer C. D., Beatty J. K., Duquette S. C., Morck D. W., Lucas M. J., Buret $A$. $G$.: Direct and indirect anti-inflammatory effects of tulathromycin in bovine macrophages: inhibition of cxcl-8 secretion, induction of apoptosis, and promotion of efferocytosis. Antimicrob. Agents Chemother. 2013, 57, 1385-1393.

8. Fleckenstein E., Uphoff C. C., Drexler H. G.: Effective treatment of mycoplasma contamination in cell lines with enrofloxacin (Baytril). Leukemia 1994, 8, 1424-1434.

9. Freshney R. I.: Culture of Animal Cells. A Manual of Basic Technique. Fifth Edition 2005.

10. Fülöpová D., Kováčik A., Kováčová R., Čupka P., Massányi P.: Effect of macrolide antibiotics on various cell cultures in vitro: 1 . cell morphology. Microbiol. Biotechnol. Food Sci. 2012, 2, 194-208.

11. Geraghty R. J., Capes-Davis A., Davis J. M., Downward J., Freshney R. I., Knezevic I., Lovell-Badge R., Masters J. R. W., Meredith J., Stacey G. N., 
Thraves P., Vias M.: Guidelines for the use of cell lines in biomedical research. B. J. C. 2014, 111, 1021-1046.

12. Godinho K. S.: Susceptibility testing of tulathromycin: interpretative breakpoints and susceptibility of field isolates. Vet. Microbiol. 2017, 129, 426-432.

13. Grubman M. J., Baxt B.: Foot and mouth disease. Clin. Microbiol. Rev. 2004, $17,465-493$

14.Hu J. F., Gilmer L., Hopkins R., Wolfinbarger L.: Effects of antibiotics on cellular viability in porcine heart valve tissue. Cardiovasc. Res. 1989, 23, 960-964.

15. Jamal S. M., Belsham G. J.: Foot-and-mouth disease: past, present and future Vet. Res. 2013, 44, 116.

16. Kováčik A., Fülöpová D., Kováčová R., Čupka P., Tušimová E., TrandžíkJ., Massányi P.: Effect of macrolide antibiotics on various cell cultures in vitro: 2. cell biochemistry. J. Microbiol. Biotechnol. Food Sci. 2012, 2, 1079-1091.

17. Lim S., Hossain M. A., Park J., Choi S. H., Kim G.: The effects of enrofloxacin on canine tendon cells and chondrocytes proliferation in vitro. Vet. Res. Commun. 2008, 32, 243-253.

18. Liu B., Cui Y., Brown P. B., Ge X., Xie J., Xu P.: Cytotoxic effects and apoptosis induction of enrofloxacin in hepatic cell line of grass carp (Ctenopharyngodon idellus). Fish Shellfish Immun. 2015, 47, 639-644.

19. Nawaz Z., Siddique A. B., Zahoor M. A., Aslam B., Zahoor M. K., Ali S.: Detection of foot and mouth disease virus shedding in milk of apparently healthy buffaloes and cattle of Punjab, Pakistan. Buffalo Bull. 2019, 38, 255-261.

20. Niedbalski W., Fitzner A., Bulenger K.: Recent progress in vaccines against foot-and-mouth disease. Med. Weter. 2019, 75, 528-533.

21. Nikfarjam L., Farzaneh P.: Prevention and detection of mycoplasma contamination in cell culture. Cell Journal 2011, 13, 203-2012.

22. Or Z. S., Fidancı U. R.: Şap virüsü ile enfekte ve așılı danalarda serum proteinlerinin elektroforetik dağılımı. Ankara Univ. Vet. Fak. Derg. 2009, 56, 13-18.

23. OIE.: Manual of diagnostic tests and vaccines for terrestrial animals. 2017, Chapter 3.1.8, 433-464.

24. Paprocka G.: Usefulness of RT-PCR in the diagnostics of foot-and-mouth disease. Med. Weter. 2009, 65, 621-623.
25. Paprocka G., Kęsy A.: Epidemiological situation of foot-and-mouth disease in 2014-2015 and the beginning of 2016. Med. Weter. 2017, 73, 131-135.

26. Perlman D.: Use of antibiotics in cell culture media. Methods in Enzymology, Vol. LVIII. Academic Press, Inc. 1979, 58, 110-116.

27. Reeves P. T.: Antibiotics: groups and properties. Chemical Analysis of Antibiotic Residues in Food, First Edition. John Wiley \& Sons, Inc. (2012).

28. Ryu A. H., Eckalbar W. L., Kreimer A., Yosef N., Ahituv N.: Use antibiotics in cell culture with caution: genome-wide identification of antibiotic-induced changes in gene expression and regulation. Sci. Rep. 2017, 7, 7533.

29. Sareyyüpoğlu B., Gülyaz V., Cokçalışkan C., Unal Y., Çökülgen T., Uzunlu E., Gürcan S., Ilk O.: Effect of FMD vaccination schedule of dams on the level and duration of maternally derived antibodies. Vet. Immunol. Immunopathol. 2019, 217, 109881

30. Tvrdá E., Kováčik A., Fülöpová D., Lukáč N., Massányi P.: In vitro impact of macrolide antibiotics on the viability of selected mammalian cell lines. J. Anim. Sci. Biotech. 2016, 49, 80-85.

31. Uphoff C. C., Denkmann S. A., Drexler H. G.: Treatment of mycoplasma contamination in cell cultures with plasmocin. J. Biomed. Biotechnol. 2012, article ID 267678.

32. UphoffC. C., Drexler H. G.: Comparative antibiotic eradication of mycoplasma infections from continuous cell lines. In vitro Cell. Dev. Biol. Anim. 2002, 38, 86-89.

33. Viluksela M., Vainio P. J., Tuominen R. K.: Cytotoxicity of macrolide antibiotics in a cultured human liver cell line. J. Antimicrob. Chemother. 1996, 38, 465-473.

34. Yarsan E.: Veteriner hekimlikte antibiyotikler: antibiyotiklere direnç ve direncin çok yönlü etkileri. 2012, tvhb.org.tr/wp-content/uploads/2019/03/

35. Xiao Y., Chen H. Y., Wang Y., Yin B., Lv C., Mo X., Yan H., Xuan Y., Huang Y., Pang W., Li X., Yuan Y. A., Tian K.: Large-scale production of foot-and-mouth disease virus (serotype Asia1) VLP vaccine in Escherichia coli and protection potency evaluation in cattle. BMC Biotechnol. 2016, 16, 56.

Corresponding author: Veli Gulyaz, Assoc. Prof. Dr. DVM, Faculty of Veterinary Medicine, Department of Virology, Harran University, ŞanlıUrfa, Turkey; e-mail: veligulyaz@yahoo.co.uk 